\title{
How the environmental planning of the Universidade Federal de Lavras impacts higher education
}

\author{
José Roberto Soares Scolforo ${ }^{1}, E_{\text {dila }}$ Vilela de Resende Von Pinho ${ }^{1}$, Antonio Chalfun-Junior ${ }^{2}$, Adriano Higino Freire ${ }^{1}$, \\ Leandro Coelho Naves ${ }^{3}$, Marcio Machado Ladeira, ${ }^{1, *}$ \\ ${ }^{1}$ Office of Rector Universidade Federal de Lavras, Campus da UFLA, Lavras, MG, Brazil, 37.200.000 \\ ${ }^{2}$ International Office of Universidade Federal de Lavras, Campus da UFLA, Lavras, MG, Brazil, 37.200.000 \\ ${ }^{3}$ Department of the Environment, Universidade Federal de Lavras, Campus da UFLA, Lavras, MG, Brazil, 37.200.000
}

\begin{abstract}
UFLA was founded in 1908 as an Agriculture School and since that time there was a large concern with environmental issues. During last decade, UFLA has started a huge expansion in different areas of knowledge, becoming a more comprehensive university rather than being focused only in Agriculture Sciences. Due to that, UFLA has faced a need to build many buildings, avenues, improve water and energy supply and deal with different residues produced by their population on campus (including at the laboratories). For this reason, in 2009, UFLA started the idea to implement an Environmental and Structural Planning (ESP), to solve current structural problems and prevent future ones, creating, by that, conditions for keeping expanding and still placing UFLA as an environmentally sustainable University. Moreover, once the Planning was implemented and, even during its implementation, UFLA started to be an excellent example and laboratory for their students. In other words, we could start teaching how to expand keeping been sustainable. For instance, almost $70 \%$ of UFLA undergraduate and graduate programs have direct or indirect relation with environment and sustainability, and part of them use facilities and activities created with the ESP implementation. As recognition for the described actions, in 2017, UFLA was ranked in 35th position in UI Green Metric overall world ranking and 1st in Education. In conclusion, the ESP is a great opportunity to improve education and research quality of UFLA.
\end{abstract}

\section{Introduction}

Universidade Federal de Lavras, The Federal University of Lavras (UFLA) was founded in 1908 as the Agricultural School of Lavras. It was renamed as the College of Agriculture of Lavras (ESAL) in 1938, when it started to offer the undergraduate program Agronomy. Then, in 1975 two new undergraduate programs were created and until 1994, when the College of Agriculture became the Federal University of Lavras, it had only 6 undergraduate Programs, $\sim 2,450$ students and $\sim 640$ employees (faculty, technicians, and administrative staff). In that time, four undergraduate Programs were in Agricultural subject and UFLA had other 10 graduate Programs in this area, which demonstrated the University expertise in Agriculture Science. Nowadays, UFLA has 35 undergraduate Programs and also 35 graduate Programs. Therefore, the University has experienced a huge expansion in the last 2 decades, and the physical and personnel increase experienced by UFLA by its history has required the adoption of new attitudes regarding environmental issues on campus. Therefore, it was necessary to build new buildings, avenues, improve water and energy supply and deal with different residues produced by their daily population and also by the use of laboratories. Currently, our academic community gathers $\sim 13,500$ students and $\sim 1,300$ employees.
As a recognition of the Environmental Planning implementation, in 2017, UFLA was ranked in $35^{\text {th }}$ position in UI Green Metric overall world ranking, $2^{\text {nd }}$ in Latin America, and $1^{\text {st }}$ in Education [1]. Therefore, this paper has the objective to describe how UFLA Higher Education is linked to environmental and sustainability issues.

\section{UFLA history and its action on agricultural science}

Until 2002 UFLA had 7 undergraduate Programs, being 5 in Agricultural subject (Fig. 1). During the last 15 years with the University expansion, new Programs have been created and it started having careers in different areas of the knowledge, as Life Sciences, Engineering, Medicine, Law, Human Science etc. However, UFLA remains as an important University in Agricultural and Environmental Sciences, having 23 out of the 35 graduate Programs in both areas (Table 1), which helps to explain why UFLA got the first position in Education in UI Green Metric Ranking. It is important to highlight that modern agriculture and livestock production is completely linked with preservation of the environment and sustainability. Some examples are: studies and practices adopted in order to mitigate greenhouse gases emission, improve soil management, decrease

\footnotetext{
* Corresponding author: mladeira@dzo.ufla.br
} 
agricultural defensive use, improve productivity and reduce carbon footprint etc.

Table 1. List of graduate programs at UFLA linked to environmental and sustainability.

\begin{tabular}{|c|}
\hline Programs \\
\hline Agriculture Engineering \\
\hline Agriculture Microbiology \\
\hline Agro chemistry \\
\hline Agronomy \\
\hline Animal Science \\
\hline Applied Botanic \\
\hline Applied Ecology \\
\hline Biomaterial Engineering \\
\hline Entomology \\
\hline Environmental Technologies and Innovations \\
\hline Feed Science \\
\hline Forestry \\
\hline Genetics and Plant Breeding \\
\hline Phytopathology \\
\hline Plant Physiology \\
\hline Soil Science \\
\hline Sustainable Development \\
\hline Vegetal Biotechnology \\
\hline Veterinary Science \\
\hline Water Resources in Agricultural Systems \\
\hline Wood Science and Technology \\
\hline \\
\hline
\end{tabular}

For instance, in 2017, UFLA professors have produced 2,958 academic publications linked to environmental and sustainability and $72.3 \%$ of the research funds were used in this area (Table 2). In addition to that, $68.4 \%$ of undergraduate and graduate courses offered were related to environmental and sustainability. In addition to traditional careers in Agriculture, new careers created at UFLA have also contributed to undergraduate and graduate programs, such as: Environmental and Sanitary Engineering, Chemical Engineering, Chemistry, Biology, Applied Ecology, Environmental Technologies and Innovations, Sustainable Development, Water Resources in Agricultural Systems.

\section{Number of undegraduate programs}

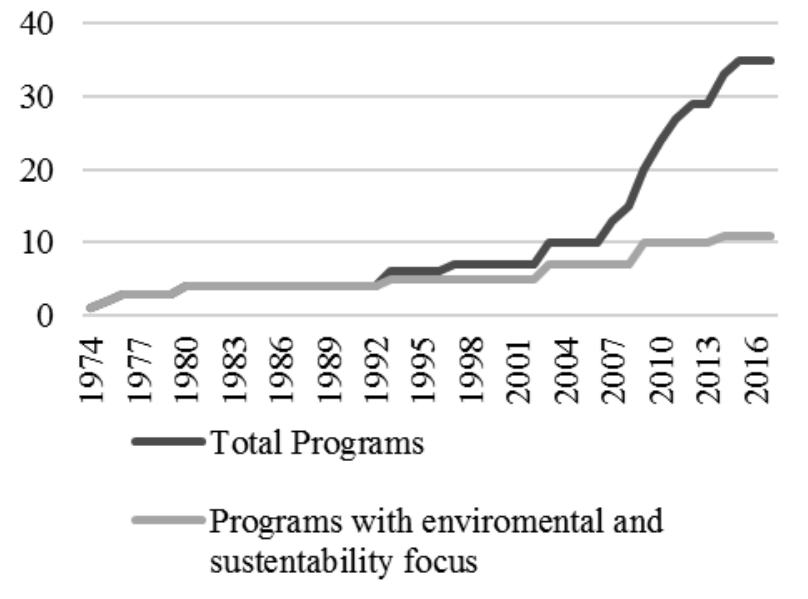

Fig. 1. Total number of undergraduate programs and the ones in Agricultural and/or Environmental sciences at UFLA since 1974.

Table 2. UFLA numbers in education used by UI GreenMetric ranking.

\begin{tabular}{|l|c|}
\hline \multicolumn{2}{|l|}{ Education item evaluated by UI Green Metric ranking } \\
\hline $\begin{array}{l}\text { Percentage of courses related with enviromental } \\
\text { and sustainability }\end{array}$ & 68.4 \\
\hline $\begin{array}{l}\text { Percentage of funds for researches in enviromental } \\
\text { and sustainability }\end{array}$ & 72.3 \\
\hline $\begin{array}{l}\text { Number of academic publications in enviromental } \\
\text { and sustainability }\end{array}$ & 2958 \\
\hline $\begin{array}{l}\text { Number of events related to enviromental and } \\
\text { sustainability }\end{array}$ & 409 \\
\hline $\begin{array}{l}\text { Number of students organizations related to } \\
\text { enviromental and sustainability }\end{array}$ & 151 \\
\hline
\end{tabular}

\section{The environmental planning of UFLA and its impact on higher education}

In 2008, UFLA elaborated an Strategic Environmental Planning, in order to create conditions for its well organized expansion. The actions that were part of this plan emerged to solve current problems and to prevent future ones, with the goal of turning UFLA into a benchmark for a Green Campus. In other words, to become UFLA one of the most sustainable and environmentally friendly university in Brazil, and also creating the bases for its community to be among the best ones in the World.

Therefore, during the implementation of the Environmental Planning, UFLA became a laboratory for many students, having direct impact in the academic training. In addition to that, after the total implementation, UFLA reduced costs of water supply, sewage treatment, and with reuse of chemical and organic waste. Total saving was around more than US\$ 2.2 million every year and that money goes direct to academic actions. 
Table 3. Example of actions developed during the implementation of the environmental planning at UFLA and their impacts on higher education.

\begin{tabular}{|c|c|}
\hline Actions & $\begin{array}{l}\text { Undergraduate } \\
\text { programs directly } \\
\text { benefited }\end{array}$ \\
\hline $\begin{array}{l}\text { UFLA improved its green areas, } \\
\text { which included an initial proposal } \\
\text { for planting }>90,000 \text { native tree } \\
\text { species that are essential for } \\
\text { protecting water springs and } \\
\text { riparian areas and for providing } \\
\text { shadow, shelter, and a pleasant } \\
\text { place to stay }\end{array}$ & $\begin{array}{l}\text { Forest Engineering, } \\
\text { Agronomy, Biology, } \\
\text { Animal Science, } \\
\text { Environmental and } \\
\text { Sanitary Engineering }\end{array}$ \\
\hline $\begin{array}{l}\text { Increase the use of clean energy } \\
\text { and its efficient, such as: a) } \\
\text { building a new protected electrical } \\
\text { network; b) replacing lampposts } \\
\text { light bulbs for more-efficient metal } \\
\text { halide ones and exchanging mixed } \\
\text { bulbs with fluorescent lamps; c) } \\
\text { building solar water heating } \\
\text { systems in all university-housing } \\
\text { buildings etc... }\end{array}$ & $\begin{array}{l}\text { Civil Engineering, } \\
\text { Physics }\end{array}$ \\
\hline $\begin{array}{l}\text { Construction of the Chemical } \\
\text { Waste Management Laboratory }\end{array}$ & $\begin{array}{l}\text { Environmental and } \\
\text { Sanitary Engineering, } \\
\text { Chemistry, Chemical } \\
\text { Engineering }\end{array}$ \\
\hline $\begin{array}{l}\text { Implementation of a Tissue } \\
\text { Digester and a Solid Waste } \\
\text { Treatment Experimental Field }\end{array}$ & $\begin{array}{l}\text { Veterinary Medicine, } \\
\text { Animal Science, Feed } \\
\text { Engineering, Chemistry, } \\
\text { Chemical Engineering, } \\
\text { Biology, Environmental } \\
\text { and Sanitary } \\
\text { Engineering, Agronomy }\end{array}$ \\
\hline $\begin{array}{l}\text { Construction of a Sewage } \\
\text { Treatment Plant }\end{array}$ & $\begin{array}{l}\text { Chemistry, Chemical } \\
\text { Engineering, Biology, } \\
\text { Environmental and } \\
\text { Sanitary Engineering }\end{array}$ \\
\hline Improve Water Treatment Plant & $\begin{array}{l}\text { Chemistry, Chemical } \\
\text { Engineering, Biology, } \\
\text { Environmental and } \\
\text { Sanitary Engineering }\end{array}$ \\
\hline $\begin{array}{l}\text { Recycling initiatives providing a } \\
\text { socially and environmentally } \\
\text { friendly final destination for most }\end{array}$ & Every student \\
\hline
\end{tabular}

\begin{tabular}{|l|l|}
\hline dry waste generated at UFLA & \\
\hline $\begin{array}{l}\text { Construction of } 8 \text { kilometers of } \\
\text { bike lanes on campus }\end{array}$ & Every student \\
\hline
\end{tabular}

In addition to the examples presented above, UFLA's awareness about the environment is also a major concern in its undergraduate and graduate programs. Undergraduate courses have in their curricula many courses dealing with environmental issues. Such actions are especially relevant taking into account results from studies applied to students in primary and higher education reporting clear evidences that those having deeper awareness (more complex view) on environment and tend to develop more meaningful pro-environmental actions [2].

\section{Summary/ concluding remarks}

The history of UFLA keeps it as one of the most important University in Agricultural Science in Latin America and due to the way modern Agriculture deals with environmental and sustainability issues, it results in a large number of courses offered and manuscripts published. Furthermore, UFLA Environmental Planning has direct and indirect impact in higher education giving to its students a better academic training. Finally, it will contribute to the awareness of society in pursuit of an environmentally sustainable economic development in Brazil and in the world.

\section{References}

1. UI Green Metric, Overall world ranking. Retrieved from: http://greenmetric.ui.ac.id/overall-ranking2017/ (2017)

2. Freitas, M. R., Macedo, R. L. G., Freitas, M. P. Environmental perception as a tool to predict proenvironmental actions. Revista Brasileira de Educação Ambiental (RevBEA), 11(1), pp. 355-360 (2016) 